\title{
Establishing and Optimizing AFLP Amplification Reaction System of Shiraia Bambusicola
}

\author{
Bing YANG ${ }^{1,2, a}$, Yi-Meng CHEN"3, ${ }^{2,3}$, Yong-Xiang LIU 2,c , Zuo-Yi LIU², \\ De-Qun $\mathrm{ZHOU}^{1, \mathrm{e}, *}$ \\ ${ }^{1}$ Faculty of Environmental Science and Engineering, Kunming University of Science and Technology, \\ Kunming 650500, China \\ ${ }^{2}$ Guizhou Key laboratory of Agricultural Biotechnology, Guizhou Academy of Agricultural Sciences, \\ Guiyang 550006, China \\ ${ }^{3}$ Fuxin Meteorological Bureau of Mongolia Autonomous County, Fuxin 123100, China \\ a315839945@qq.com, b317010321@qq.com, kittyliu0211@163.com, dgzliuzuoyi@163.com, \\ e1549284671@qq.com
}

Keywords: Shiraia Bambusicola, AFLP, System Optimizing, Polymorphic Primer.

\begin{abstract}
DNA of Sharaia bambuiscola was extracted by the improved method of CTAB. The several key factors affecting the effect of DNA digestion and the PCR selective amplification such as the time of DNA digestion, the times of the per-amplified dilute products, the mount of the selective amplification primer, Taq concentration and dNTPs concentration were optimized and trialed with establishment of an optimized AFLP reaction system of S. bambusicola. The best time of digestion DNA with double endonucleases (EcoR I and Mse I ) was $3 \mathrm{~h}$. The optimized selection amplification system was $25 \mu 1$ reaction mix containing $2.5 \mu 1$ the 20 times of the per-amplified dilute products, $2.5 \mu \mathrm{L} 10 \times$ buffer(with $\mathrm{Mg}^{2+}$ ), $10 \mathrm{mmol} / \mathrm{L}$ primer each $1.5 \mu \mathrm{L}, 2.5 \mathrm{U} \cdot \mu \mathrm{L}^{-1}$ Taq polymerase $0.7 \mu \mathrm{L}$, $10 \mathrm{mmol} / \mathrm{L}$ dNTP $0.5 \mu \mathrm{L}$, and $15.8 \mu \mathrm{L} \mathrm{ddH_{2 }} \mathrm{O}$. Stable and clean DNA finger print can be obtained and 3 pairs of AFLP primers with good genetic diversity were selected according to the optimized reaction system. The results will be an effective protocol for further studying the genetic stucture and differentiation, phylogenetic trees, host specificity and artificial cultivation of Shiraia bambusicola population.
\end{abstract}

\section{Introduction}

Shiraia bambuiscola P. Hennings has been reported as a parasitic medicinal fungus on branches of bamboo. It is widely applied in various fields such as biological technology and medicine. But the phylogeny is unclear. Recently, the research results show that a new family Shiraiaceae (Pleosporale, Dothideomycetes, Ascomycota) was established with S. bambusicola as representative gene and species[1]. Stromata of S. bambusicola has a long history as a traditional Chinese medicine, and are the raw material for extracting of hypocrellin[2]. Hypocrellin is promising in the photodynamic therapy (PDT) for anticancer treatment [3,4]. Furthermore, it has a striking function to kill tumor cells, inhibit viruses, cure diabetic retinopathy and against human immunodeficiency virus type 1(HIV-1)[5-8].

S. bambusicola is distributed in southern China and Japan[9]. Sri Lanka is hopefully one of distribution regions[10]. But the biomass of the fungus is very limited. Driven by market demand, the wild resource of S. bambusicola has been overexploited and become scarce[11]. The fungus and its genetic diversity has not been sufficiently studied.

S. bambusicola is discontinuously distributed in China and Japan[9], which may results in rich genetic diversity within the species but from different geological locations. RAPD (Random Amplified Polymorphic DNA) was used to analyze genetic differentiation of S. bambusicola populations from east China[12]. However, little has been done in the genetic diversity. 


\section{Materials and Methods}

\section{Materials}

35 test materials of Shiraia bambusicola were collected from Anhui, Zhejiang, Guizhou provinces; primers and adapter (JieLi); $10 \mathrm{U} / \mu \mathrm{L}$ of EcoR I , 10U/ $\mu \mathrm{L}$ of Mse I (Thermo), $5 \mathrm{U} / \mu \mathrm{L}$ of $\mathrm{T}_{4}$ DNA ligase, $2.5 \mathrm{U} / \mu \mathrm{L}$ of Taq DNA polymerase (buffer with $\mathrm{Mg}^{2+}$ ), $10 \mathrm{mmol} / \mathrm{L}$ each of dNTPs (Zomanbio) were applied.

\section{Methods}

DNA Extraction. DNA of Shiraia bambusicola was extracted by the modified CTAB[13-14] and detected by using $0.8 \%$ agarose gel electrophoresis.

\section{Establishment and Optimization of AFLP Reaction System}

Enzyme Digestion and Ligation. EcoR I and Mse I were used for double enzyme digestion. The enzyme digestion system is shown in Table 1. Enzyme digestion time is an important factor for the result. Enzyme digestion time was set 4 gradients for 2, 3, 4 and $5 \mathrm{~h}$ in this research. The result was detected by using $0.8 \%$ agarose gel electrophoresis. Then the ligation reaction was conducted at $16^{\circ} \mathrm{C}$ after the single stranded adapter (Table 2) become double. The time of reaction was $12 \mathrm{~h}$. Ligation reaction system is also shown in Table 1.

Tab. 1. Part of the AFLP reaction system

\begin{tabular}{|c|c|c|c|c|c|}
\hline \multicolumn{2}{|c|}{ Enzyme digestion $/ \mu \mathrm{L}$} & \multicolumn{2}{|c|}{ Ligation $/ \mu \mathrm{L}$} & \multicolumn{2}{|c|}{ Per-amplification $/ \mu \mathrm{L}$} \\
\hline Total volume & 20 & Total volume & 20 & Total volume & 25 \\
\hline Template DNA & 5 & $\begin{array}{l}\text { Digestion } \\
\text { products }\end{array}$ & 15 & Ligase products & 2.5 \\
\hline EcoR I & 0.5 & EcoR I adapter & 1 & E00 primer & 1 \\
\hline Mse I & 0.5 & Mse I adapter & 1 & M00 primer & 1 \\
\hline $\begin{array}{c}\text { 10xTango } \\
\text { buffer }\end{array}$ & 2 & T4 buffer & 2 & $10 \times$ Taq buffer & 2.5 \\
\hline $\mathrm{ddH}_{2} \mathrm{O}$ & 12 & T4 DNA ligase & 1 & Taq & 0.5 \\
\hline & & & & dNTP & 0.5 \\
\hline & & & & $\mathrm{dd}_{2} \mathrm{O}$ & 17 \\
\hline
\end{tabular}

Amplification Reaction. After the ligation reaction, two PCR amplification were reacted. The per-amplification and the selective amplification was conducted. The per-amplification primer were E00 and M00 (Table 2), and the reaction system was shown in Table 1. Per-amplification PCR reaction was performed under the following thermal conditions: initial denaturation at $95^{\circ} \mathrm{C}$ for $3 \mathrm{~min}$; 30 cycles of denaturation at $95^{\circ} \mathrm{C}$ for $30 \mathrm{~s}$; annealing at $55^{\circ} \mathrm{C}$ for $30 \mathrm{~s}$; an extension at $72^{\circ} \mathrm{C}$ for $1 \mathrm{~min}$, and a final extension at $72^{\circ} \mathrm{C}$ for $7 \mathrm{~min}$. The final products were stored at $-20^{\circ} \mathrm{C}$.

Tab. 2 The swquences of all adapter and primer in experiment

\begin{tabular}{lcl}
\hline Sequences of adapter and primer & \\
\hline Double stranded adapter & EcoR I & 5-CTC GTA GAC TGC GTA CC-3 \\
& & 3-CAT CTG ACG CAT GGT TAA-5 \\
& Mse I & 5-GAC GAT GAG TCC TGA G-3 \\
& & 3-TA CTC AGG ACT CAT-5 \\
Per-amplification primer & E00 & 5-GAC TGC GTA CCAAT TCA-3 \\
& M00 & 5-GAT GAG TCC TGA GTA AC-3 \\
\hline
\end{tabular}


Tab. 3 The swquences of all adapter and primer in experiment (Cont.)

\begin{tabular}{lll}
\hline Sequences of adapter and primer & \\
$\begin{array}{l}\text { Selective amplification } \\
\text { primer }\end{array}$ & E1-ACT & 5-GACTGCGTACCAATTCACT-3 \\
& E2-AAC & 5-GACTGCGTACCAATTCAAC-3 \\
E3-AAG & 5-GACTGCGTACCAATTCAAG-3 \\
E4-ACA & 5-GACTGCGTACCAATTCACA-3 \\
E5-AGG & 5-GACTGCGTACCAATTCAGG-3 \\
E6-ACG & 5-GACTGCGTACCAATTCACG-3 \\
E7-AGC & 5-GACTGCGTACCAATTCAGC-3 \\
E8-ACC & 5-GACTGCGTACCAATTCACC-3 \\
M1-CAG & 5-GATGAGTCCTGAGTAACAG-3 \\
M2-CAC & 5-GATGAGTCCTGAGTAACAC-3 \\
M3-CTC & 5-GATGAGTCCTGAGTAACTC-3 \\
M4-CTG & 5-GATGAGTCCTGAGTAACTG-3 \\
M5-CAA & 5-GATGAGTCCTGAGTAACAA-3 \\
M6-CTA & 5-GATGAGTCCTGAGTAACTA-3 \\
M7-CAT & 5-GATGAGTCCTGAGTAACAT-3 \\
M8-CTT & 5-GATGAGTCCTGAGTAACTT-3 \\
\hline
\end{tabular}

In the selective amplification reaction system, different gradients of 4 factors were set for the amount of per-amplification products, Taq, dNTP, primers as well: the total selective amplification reaction system was $25 \mu \mathrm{L}$, the additive amount of per-amplification products was $2.5 \mu \mathrm{L}$. The seven gradients of the times of per-amplification dilute products we set, including 5, 10, 20, 40,60,80 and 100 times; concentration of Taq was $2.5 \mathrm{U} / \mu \mathrm{L}$, and 6 gradients of additive amount we set, including $0.1,0.3,0.5,0.7,0.9$ and $1.1 \mu \mathrm{L}$; concentration of dNTP was $10 \mathrm{mmol} / \mathrm{L}$, and 6 gradients of additive amount we set, including $0.1,0.3,0.5,0.7,0.9$ and $1.1 \mu \mathrm{L}$; concentration of primer was $10 \mathrm{mmol} / \mathrm{L}$, and 6 gradients of additive amount we set, including $0.5,1.0,1.5,2.0,4.0$ and $6.0 \mu \mathrm{L}$. Reaction with a single variable each time. Finally, the reaction system contained $2.5 \mu \mathrm{L}$ of $10 \times$ Taq buffer $\left(\right.$ with $\mathrm{Mg}^{2+}$ ) and $\mathrm{ddH}_{2} \mathrm{O}$ was added to the final volume. The reaction amplification has two steps, gradient cooling amplification and common amplification. The first step was initial denaturation at $95^{\circ} \mathrm{C}$ for $3 \mathrm{~min} ; 13$ cycles of denaturation at $95^{\circ} \mathrm{C}$ for $30 \mathrm{~s}$; annealing at $60^{\circ} \mathrm{C}$ for $30 \mathrm{~s}$; an extension at $72^{\circ} \mathrm{C}$ for $1 \mathrm{~min}$, the annealing temperature of each cycle was declined $0.7^{\circ} \mathrm{C}$ in this step. And the secong step was 30 cycles of denaturation at $95^{\circ} \mathrm{C}$ for $30 \mathrm{~s}$; annealing at $53^{\circ} \mathrm{C}$ for $30 \mathrm{~s}$; an extension at $72^{\circ} \mathrm{C}$ for $1 \mathrm{~min}$, and a final extension at $72^{\circ} \mathrm{C}$ for $7 \mathrm{~min}$.

After reaction, $5 \mu \mathrm{L}$ volume of denaturing sample buffer $(98 \%$ of deionized formamide, $10 \mathrm{mmol} / \mathrm{L}$ EDTA, $0.25 \%$ of bromophenol blue and $0.25 \%$ of xylene cyanol FF) was added into $20 \mu \mathrm{L}$ volume of selective amplification products for $5 \mathrm{~min}$ of denaturing at $95^{\circ} \mathrm{C}$, and then immediately placed into ice mixture to prevent the products from renaturation. The per-electrophoresis was carried out for 30min with $6 \%$ denaturing polyacrylamide gel under constant power of $70 \mathrm{~W}$, after sample application, electrophoresis was carried out for about $2 \mathrm{~h}$ under constant power of $70 \mathrm{~W}$, and then the silver staining continued for further analysis[14,15].

\section{Results and Analysis}

\section{DNA Detection}

The electrophoresis bands had shown good with no impurities (Fig. 1), which Indicates that the genomic DNA we extracted by modified CTAB were high-quality, and suitable for analysis. 


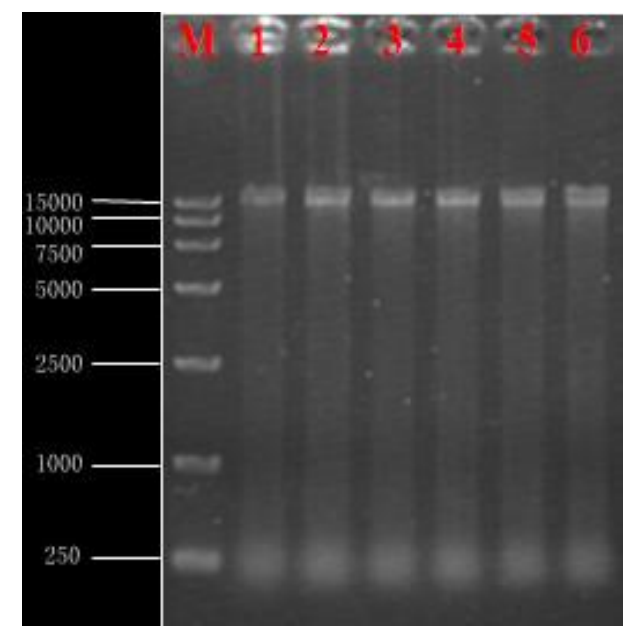

Note: M:Marker DL 15000; 1 6: Six different samples

Fig.1 The electrophoresis results of genomic DNA

\section{Enzyme Digestion and Ligation}

Double enzyme digestion was used in the enzyme and ligation reaction. The 4 gradients of enzyme digestion time were detected. As Fig. 2 shown that the electrophoresis bands were uniformly scattered without main band. This result indicates that double enzyme digestion was able to digest genomic DNA, and the complete digestion time was $3 \mathrm{~h}$. The enzyme digestion products were good templates for ligation reaction.

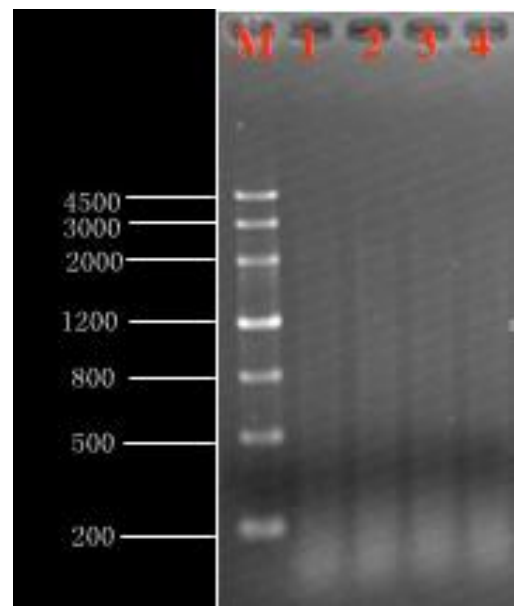

Note: M:MarkerIII; 1 4: Severally, the digestion time was 2, 3, 4, $5 \mathrm{U}: \mathrm{h}$

Fig. 2 The results of different enzyme digestion time

\section{Amplification and Optimization}

The pairs E00 and M00 were added into the products from Enzyme digestion and ligation reaction. After the PCR per-amplification, the small uniforml scattered bands which about from 50bp to 500bp were obtained. Not only the results of ligation reaction were detected in this process, but also the templates of next step were prepared.

In the selective amplification reaction system, different gradients of 4 key factors were set for optimizing the system. Four key factors include the times of the per-amplified dilute products, the mount of selective amplification primer, Taq concentration and dNTPs concentration. The results were detected by using $2.5 \%$ agarose gel electrophoresis, and the optimized reaction system was obtained finally.

As shown in Fig. 3, different bands were observed from different times of per-amplification dilute products. The additive amount was $2.5 \mu \mathrm{L}$, and the band which dilute from 5 times to 20 times was better and clearer than the others. When the times was more than 20 , the bands were weaker and 
amplificated deficiently. According to the results, the selective amplification system with 20 times of per-amplification dilute products was the best times.

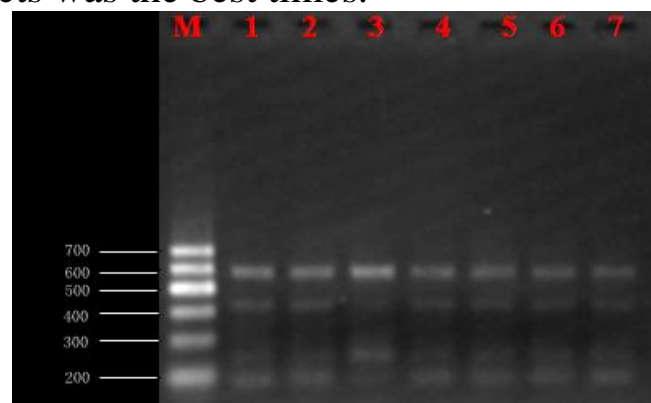

Note: M:Marker I ; 1 7: Severally, the diluted times were 5, 10, 20, 40, 80, 160, 320 U:time

Fig. 3 The electrophoresis results of selective amplification with different diluted times of pre-amplification products

As shown in Fig. 4, with 10mmol/L concentration of primer, the bands with $1.5 \mu \mathrm{L}$ additive amount were observed of clearer and higher polymorphism. When the additive amount was less than $1.5 \mu \mathrm{L}$, the bands were weaker and amplificated deficiently. When the addtive amout was more than $1.2 \mu \mathrm{L}$, the nonspecific amplification had significantly increased. The selective amplification system with $1.5 \mu \mathrm{L}$ primer $(10 \mathrm{mmol} / \mathrm{L})$ was the best volume.

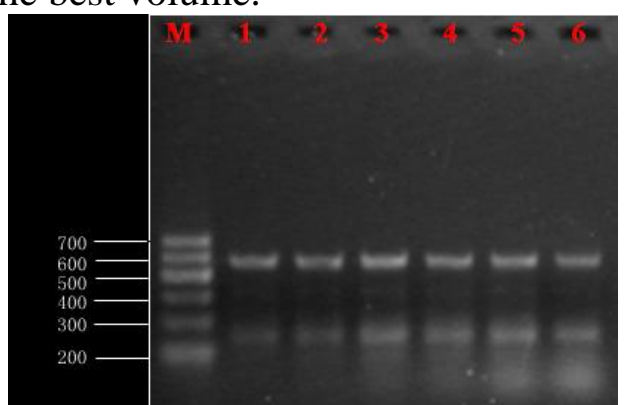

Note: M:Marker I ; 1 6: Severally, the primer (10mmol/L) volume was 0.5, 1.0, 1.5, 2.0, 2.5, 3.0 $\mathrm{U}: \mu 1$

Fig. 4 The electrophoresis results of selective amplification with different primer volume

As shown in Fig. 5, the concentration of Taq polymerase was $2.5 \mathrm{U} / \mu \mathrm{L}$, and we could observe the bands which additive amount was from $0.7 \mu \mathrm{L}$ to $1.2 \mu \mathrm{L}$ were better, clearer and higher polymorphism. When the additive amount was less than $0.7 \mu \mathrm{L}$, the bands were weaker and amplificated deficiently, there would be less or even no the products. When the addtive amout was more than $1.2 \mu \mathrm{L}$, the nonspecific amplification had significantly increased. According to the results, the selective amplification system with $0.7 \mu \mathrm{L}$ Taq polymerase $(2.5 \mathrm{U} / \mu \mathrm{L})$ was the best volume.

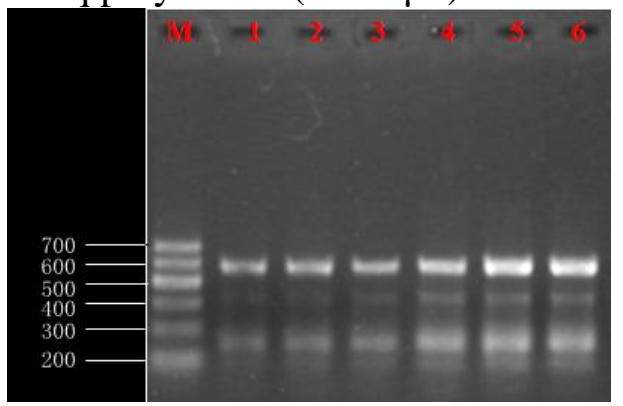

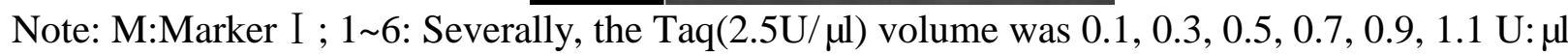

Fig. 5 The electrophoresis results of selective amplification with different Taq volume

As shown in Fig. 6, with 10mmol/L the concentration of dNTP, the bands of the additive amount from $0.5 \mu \mathrm{L}$ to $2.0 \mu \mathrm{L}$ were o with better, clearer and higher polymorphism. When the additive amount 
was less than $0.7 \mu \mathrm{L}$, the bands were weaker and amplificated deficiently, there would be less or even no the products. According to the results, the selective amplification system with $0.5 \mu \mathrm{L}$ $\mathrm{dNTP}(10 \mathrm{mmol} / \mathrm{L})$ was the best volume.

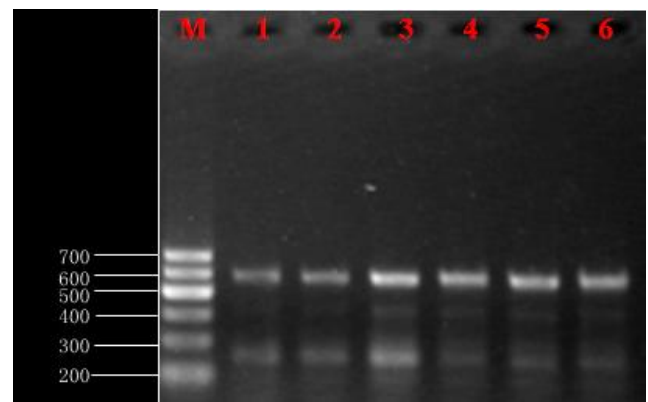

Note: M:Marker I ; 1 6: Severally, the dNTP(10mmol/L) volume was 0.1, 0.3, 0.5, 0.7, 0.9, $1.1 \mathrm{U}: \mu 1$

Fig. 6 The electrophoresis results of selective amplification with different dNTP volume

After explored the 4 factors affecting the effect of PCR selective amplification, An optimizing AFLP reaction system could be obtained (Table 3 ). The detection results by using agarose gel electrophoresis primary as Fig. 7, and the results by using denaturing polyacrylamide gel are shown in Fig. 8.

Tab. 3 Optimizing selection amplification of Shiraia bambusicola

\begin{tabular}{cc}
\hline Total volume & $25[\mu \mathrm{L}]$ \\
\hline Per-amplification dilute products(20 times) & 2.5 \\
PrimerE $(10 \mu \mathrm{M})$ & 1.5 \\
PrimerM $(10 \mu \mathrm{M})$ & 1.5 \\
10× Taq buffer(with $\left.\mathrm{Mg}^{2+}\right)$ & 2.5 \\
Taq $(2.5 \mathrm{U} / \mu \mathrm{l})$ & 0.7 \\
$\mathrm{dNTP}(10 \mu \mathrm{M})$ & 0.5 \\
$\mathrm{ddH}_{2} \mathrm{O}$ & 15.8 \\
\hline
\end{tabular}

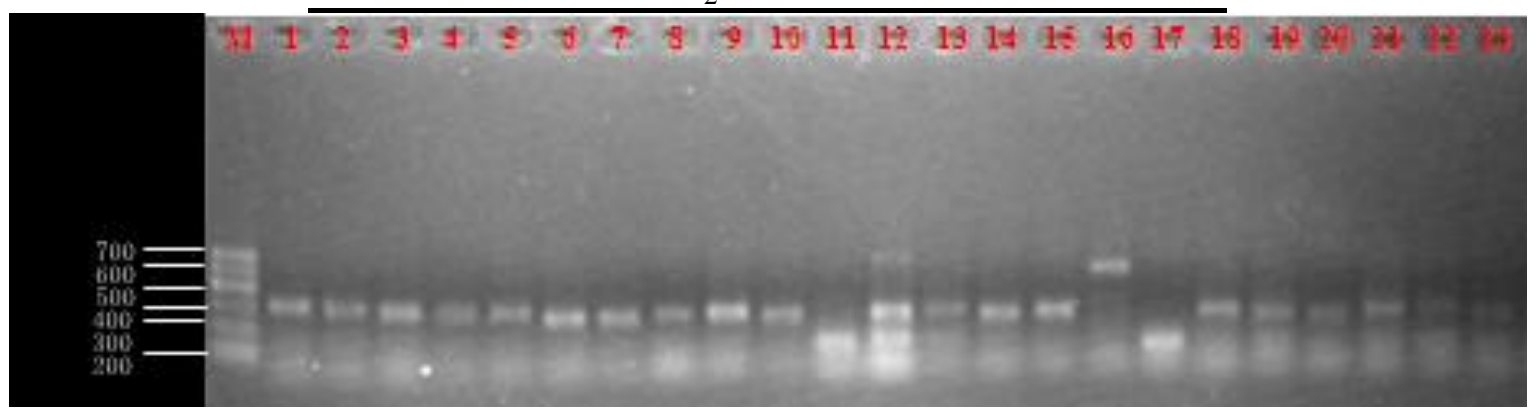

Note: M:Marker I ; 1-23: Twenty-three different samples

Fig. 7 The agarose electrophoresis results of the optimized selective amplification reaction system

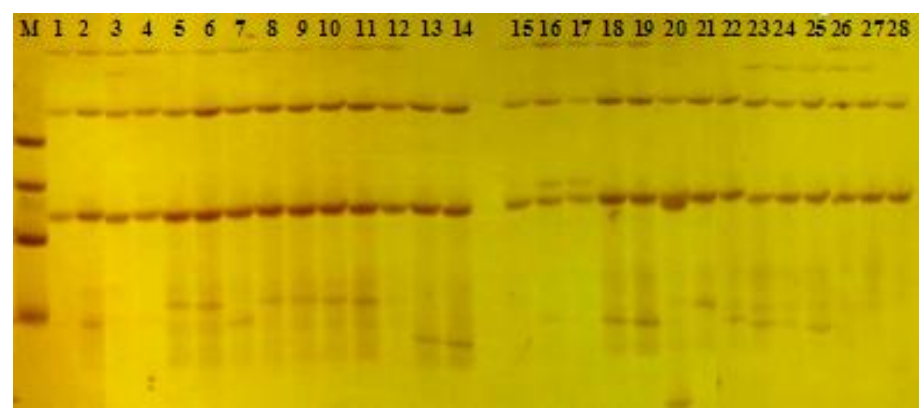

Note: M:Marker I ; 1-28: Twenty-eight different samples

Fig.8 The polyacrylamide gel electrophoresis results of the optimized selective amplification 
Screening Primer Primary. Different amplification effect were obtained through different pairs of primers between different genomic DNA[16]. Screening the suitable pairs of primers was the key to conclude polymorphism. Three pairs of primers from 64 pairs by using $2.5 \%$ agarose gel electrophoresis through observed bands were screened. The bands of 3 pairs primers were more and clearer (Fig. 9). The three pairs are E2-AAC/M4-CTG, E3-AAG/M2-CAC and E3-AAG/M4-CTG.

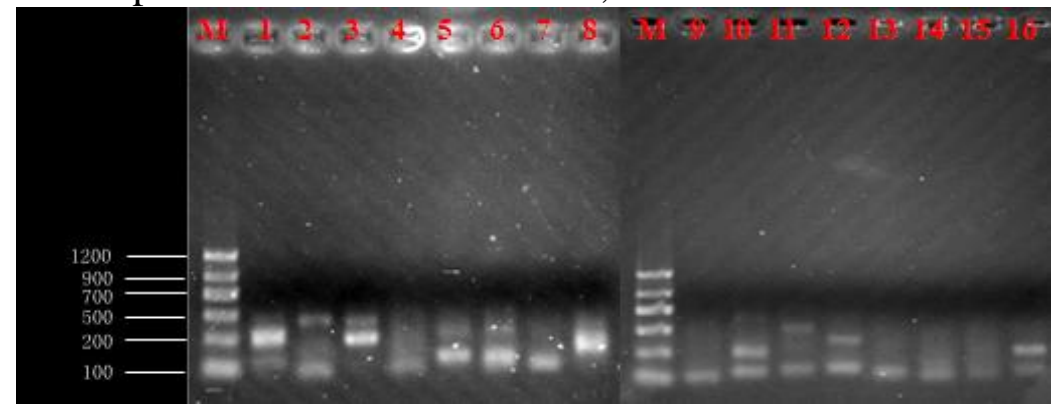

Note: M:Marker II ; 1 16: Severally, the primer combination was 11, 12, 13, 14, 21, 22, 23, 24, 31, 32, $33,34,41,42,43,44$

Fig. 9 Detection of selective amplification with different pairs of primers

\section{Discussion}

An AFLP reaction system of S. bambusicola was first established in this study. The several key factors affecting the effect of DNA digestion and the PCR selective amplification were explored and optimized. The results showed that extracted DNA by the improved method of CTAB is suitable for the AFLP system with the high quality DNA. Three hours of enzyme digestion was digested fully with the desired results of enzyme digestion and ligation reaction. The optimizing selection amplification system was $25 \mu \mathrm{L}$ reaction mix containing $2.5 \mu \mathrm{L}$ the 20 times of the per-amplified dilute products, $2.5 \mu \mathrm{L} 10 \times$ buffer(with $\mathrm{Mg}^{2+}$ ), $10 \mathrm{mmol} / \mathrm{L}$ primer each $1.5 \mu \mathrm{L}, 2.5 \mathrm{U} / \mu \mathrm{L}$ Taq polymerase $0.7 \mu \mathrm{L}$,

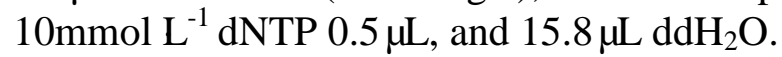

\section{Acknowledgements}

This work was financially supported by the by NSFC (2012) 31160160, NSFC (2015) 31460199 and QNKYYZX (2012) 010.

\section{References}

[1] Y X LIU, K D HYDE, H A ARIYAWANSA, et al. Shiraiaceae, new family of Pleosporales (Dothideomycetes, Ascomycota)[J]. Phytotaxa, 2013, 103(1):51-60.

[2] Y Liu, Z Liu, Wongkaew. Developing characteristics and relationships of Shiraia bambusicola with Bamboo[J]. Sonklanakarin Journal of Science and Technology, 2012, 34(1):17.

[3] Y Su, J Sun, S Rao, et al. Photodynamic antimicrobial activity of hypocrellin A[J]. Journal of Photochemistry and Photobiology B: Biology, 2011, 103(1):29-34.

[4] J Zhang, E H. Cao, J F Li, et al. Photodynamic effects of hypocrellin A on three human malignant cell lines by inducing apoptotic cell death[J]. Journal of Photochemistry and Photobiology B: Biology, 1998, 43(2):106-111.

[5] H L Yang, F R Huang. Quantum chemical and statistical study of hypocrellin dyes with phototoxicity against tumor cells[J]. Dyes and pigments, 2007, 74(2):416-423.

[6] Y Chen, Y X Zhang, M H Li, et al. Antiangiogenic activity of 11, 11-dideoxyverticillin, a natural product isolated from the fungus Shiraia bambusicola $[\mathrm{J}]$. Biochemical and biophysical research communications, 2005, 329(4):1334-1342. 
[7] J Hudson, J Zhou, J Chen, et al. Hypocrellin, from Hypocrella bambuase, is phototoxic to human immunodeficiency virus[J]. Photochemistry and photobiology, 1994, 60(3):253-255.

[8] Y Tong, X Zhang, W Zhao, et al. Anti-angiogenic effects of Shiraiachrome A, a compound isolated from a Chinese folk medicine used to treat rheumatoid arthritis[J]. European journal of pharmacology, 2004, 494(2):101-109.

[9] D Morakotkarn, H Kawasaki, T Seki. Molecular diversity of bamboo-associated fungi isolated from Japan[J]. FEMS microbiology letters, 2006, 266(1):10-19.

[10] S M Ali, M Olivo. Efficacy of hypocrellin pharmacokinetics in phototherapy[J]. International Journal of Oncology, 2002. 21(6):1229-1237.

[11] Y Liu, Z Liu, Y Yang. Isolation, Screening and Confirmative Identification of High Hypocreliin A-Producing Shiraia bambusicola Iso-lates[J]. Khon Kaen Agriculture Journal, 2009, 37(4):357-364.

[12] Y Fan, C G Zhong, J Cheng, et al. Genetic Differentiation of Shiraia bambusicola Populations from East China Revealed by RAPD Analysis [J]. Genomics and Applied Biology, 2009,28(5): 889-895.

[13] Y J Xu, Y Liu. Establishment and Optimization of AFLP Markers in Momordica charantia L. [J]. Chinese Agricultural Science Bulletin, 2012. 28(4):125-130.

[14] M. ShuChun, M. Yi, G. Jun, et al. A preliminary study on the establishment of AFLP reaction system in spinach[J]. Agricultural Science \& Technology-Hunan, 2012. 13(2):268-272.

[15] Y J Wang, L S Wu, S H Li, et al. The influence of several kinds of drugs for polyacrylamide gel electrophoresis with silver staining[J]. Reservoir Fisheries, 2005, 25(2):13-14.

[16] P Vos, R Hogers, M Bleeker, et al. AFLP: a new technique for DNA fingerprinting[J]. Nucleic acids research, 1995, 23(21):4407-4414. 